\title{
Who is Teaching (or Not Teaching) Mexican Youth in Southeast Idaho About Safer Sex Practices?
}

\author{
Peter C. Davis ${ }^{1}$ and Linda L. Rankin ${ }^{2}$ \\ ${ }^{1}$ Idaho State University - Boise Center, Institute for Rural Health \\ ${ }^{2}$ Idaho State University, Department of Health and Nutrition Sciences
}

\begin{abstract}
Because of the high rate of HIV/AIDS in the Hispanic community, the original purpose of this qualitative study ( $\mathrm{n}=20$ ) was to investigate the explanatory models of HIV and AIDS in Mexican migrant women in southeast Idaho. However, a reoccurring theme emerged that pointed toward the possibility of a breakdown in communication between the Mexican migrant families and the education system regarding sex education. Eighty percent of the women interviewed believed that their children were receiving education about condoms and safer sex practices in the school, while in reality the students were only receiving abstinence-based sex education. Since the women believed that their children were being educated in school, there was no dialogue in the family unit about safer sex practices. Because of the high rate of HIV/AIDS and teen pregnancy in the Hispanic community in the United States, it is important to examine this lack of education as a possible catalyst to these problems.
\end{abstract}

(C) 2006 Californian Journal of Health Promotion. All rights reserved.

Keywords: Hispanic teen health, sexuality education, safe sex, HIV/AIDS

\section{Introduction}

The United States has a large and growing Hispanic population that is heavily affected by the HIV/AIDS epidemic. Hispanics represent $13.7 \%$ of the U.S. population (including residents of Puerto Rico), but accounted for $20.5 \%$ of the total number of new U.S. AIDS cases reported in 2004 (Centers for Disease Control and Prevention [CDC], 2004).

Different subgroups of Hispanics living in the U.S. face different challenges regarding HIV risk. Among other factors, such challenges depend on how their identities and sexual and drug-related behaviors change after moving to the U.S., their access to health services, appropriate HIV education, and condoms, norms about safe sex and drug use in their new communities, the nature of their relationships with sexual partners in the U.S. and in Mexico, and the level to which they experience racism, discrimination, and poverty in the U.S. (Rangel \& Lozado, 2003).
There is conflicting literature about whether or not acculturation helps in the prevention of HIV or detracts from prevention of HIV. Several authors argue that Mexicans who are less acculturated into American values are less likely to engage in high-risk behaviors because of their conventional, Latino sexual morals (Peragallo, 1996; Newcomb et al., 1998). Other researchers argue that acculturation into the individualistic American society can help to create a sense of control and self-efficacy regarding sexual practices (Marin, Tschann, Gomez, \& Kegeles, 1993; Marks, Cantero, and Simoni, 1998).

In Idaho, Hispanics account for $10 \%$ of all people with HIV and for $9 \%$ of all people with AIDS (Idaho Department of Health and Welfare [IDHW], 2006). It is assumed that the Hispanics tested have some sort of access to health care. However, much of the Hispanic population in southeast Idaho does not have access to health care because of their illegal status and they are therefore not tested. 
Although the Centers for Disease Control (CDC) report that, epidemiologically, the numbers point to only a small number of HIV positive people in the Hispanic communities of southeast Idaho (IDHW, 2006), it is possible to hypothesize that there are people who are HIV positive and are not aware of their status because they do not have access to testing, or are afraid to get tested because of their immigration status. Thus, the HIV positive population is likely much higher than reported.

Because the Hispanic population is often marginalized, this study strived to bridge the gap between the biomedical explanatory model of HIV and the cultural explanatory model ideal of HIV which Mexican migrant women in southeast Idaho embody. While working to bridge this gap, a surprising theme emerged from personal interviews. This theme was one of a lack of discourse between parents, children and schools about safer sex practices.

The study was qualitative in nature and utilized one-on-one interviews. The interview questions were based on five general themes that were identified in two previous studies that examined myths and ideas regarding HIV and AIDS in Mexicans in southeast Idaho (Cartwright \& Solis, 2002; Stahlman, 2004). The five themes that were discussed during the interview were: what is HIV; where does HIV come from; who gets HIV; what are the community's perceptions of HIV; and what are the health concerns of the community.

\section{Methodology}

The principal investigator conducted 20 interviews using open-ended questions with Mexican women in the American Falls, Idaho area. The interview questions were open-ended but specifically asked individuals about individual and cultural beliefs regarding HIV, cultural views of biomedicine, possible barriers to obtaining medical services, general knowledge about HIV/AIDS, and community perceptions regarding the disease and people who have the disease.

The questions were translated by the principal investigator, checked for cultural accuracy by four female community members whose first language is Spanish, and then back translated by the researcher. Along with grammatical and dialectical suggestions, the community members also made suggestions to help refine the questions to best fit the Hispanic population in southeast Idaho

Snowball sampling was utilized as a way to recruit participants into the study. Snowball sampling is a non-random method of recruiting participants that employs the social networks of individuals to access other possible informants (Rice \& Ezzy, 1999). Because this is a nonrandom method of recruitment, there is a possible selection bias in the sample. However, snowball sampling has been shown to be successful in other projects with a comparable design (Stahlman, 2004).

The principal investigator began the interviews with primary informants, Health Promoters (Promotoras) from the Hispanic Health Projects. The Hispanic Health Projects at the Department of Anthropology at Idaho State University, is a grass roots based organization that engages community members, academic professionals, service providers and policy makers in efforts that increase health status and health awareness in southeast Idaho and Mexico. From those informants the researcher was directed to other possible informants and from those informants often received the names of other possible informants.

All of the informants were female, Mexican, ranged between the ages of 18 and 61, with 35.8 being the mean age. All women were able to fully understand the consent form before the interview started and, all of the participants spoke Spanish as their first language. However, several of the participants also spoke fluent English. The interviews were conducted in the language of choice of the participant. All interviews were conducted in the Hispanic Health Project office in American Falls, Idaho, the home of the participant, or the house of a friend of the participant. All interviews were then transcribed and coded by the researcher. 


\section{Results}

One of the themes that emerged from the interviews was in regards to discourse between women and their children about condoms and sexuality education. Many of the women assumed that the children were receiving sex education in the schools. It could be hypothesized that this is due to the fact that there is universal sex education in public Mexican schools. Safer sex practices such as using condoms are taught. However, the American Falls school district has an abstinence-based sex education program that does not allow for condom demonstrations or discussion of condoms in the schools.

The results showed that $80 \%$ of the women believed that their children were learning about condoms in the public school education system. Some of the responses that addressed this lack of communication include the following:

P-Si, ¿Cómo se aprende cerca de los condones?

R-También enseñan (sobre condones) en las escuelas, enseña muchos a los niños. Es una manera de ayudar como padres, para prevenir contra las enfermedades y embarazos.

They also teach (about condoms) in the schools. They teach a lot to the kids. It is a way of helping parents, to prevent against sicknesses and pregnancies.

$\underline{\text { Interview J9 }}$

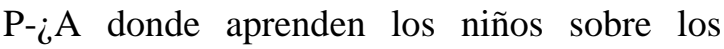
condones?

Where do the children learn about condoms?

$\mathrm{R}$-Creo que en la escuela, en sus clases sobre eso. Mi hija me dijo que ellos están enseñando estas cosas en sus clases.

I think that in school, in their classes about this subject. My daughter told me that they are teaching these things in her class.

Interview 4E

Most likely these ideals were brought from Mexico where sex education is centralized and mandated nationwide through what would be the American equivalent of the Secretary of Education. In Mexico, condom use and safer sex activities are taught to all children 12 years old and older, via the public school system.

P-¿Como aprende uno acerca de los condones?

How does one learn about condoms?

R-Usualmente en la escuela.

Usually in school.

$\mathrm{P}-\dot{¿}$ En la escuela?

In school?

$\mathrm{R}$-Si, ellos tienen clases de cómo usar un condón en las escuelas.

Yes, they have classes on how to use condoms in the schools.

P-¿Aquí o en México?

Here or in Mexico?

R-De seguro en Mexico. Creo que aquí tambien.

For sure in Mexico. But, I think here as well. Interview 15P

\section{Analysis}

The mothers' beliefs that their children were receiving information about how to use condoms raises several alarming public health questions. The first and most pertinent is the fact that the children are not getting enough information to properly protect them, if they decide to engage in sexual relations. This lack of knowledge of safer sex practices, namely condom use, could create a situation in which the young people become infected with sexually transmitted infections, or the possibility of pregnancy. Also, there is a possibility that the parent may have a conversation with their child about sex, addressing the emotional aspects of sex, but not addressing the biological health issues of a sexually active person. This could lead to the child believing that engaging in sexual intercourse is acceptable, without having the tools to protect themselves when engaging in the behavior.

Some people may disagree that sexuality is openly discussed within Latino families. However, we found this assumption to be the opposite, with $80 \%$ of women saying that they would be open to discussing this topic with their children. In any case, if the women are discussing sex and sexuality with their children in a manner that assumes that the children have a 
baseline idea of safer sex practices, the discussion which is sex positive may initiate the child to engage is high risk sexual activity with only the knowledge of abstinence-based education and without the tools to properly protect themselves.

\section{Conclusion}

Admittedly, there are limitations to this study. The women may not have been open with the principal investigator, who is a white male, not from their community. Also, the children could have been receiving information about safer sex practices either directly or indirectly from male family members. Chances are that the women would not have known about these communications.

It is necessary to not only educate the students in the public schools, but it is also necessary to educate the parents about what is being taught in the school system. This is most relevant in the case of health and sexuality education. It is possible to argue that English speaking parents may be in the same scenario, not knowing what is being taught to their children in sex education classes, and thus not providing accurate information to their children, if they do decide to have sex. However, the problems seems to be more pressing in the Latino community, as Hispanics have a higher rate per capita of both HIV and teen pregnancy (Hamilton, Ventura, Martin, and Sutton, 2003). And, although there might be other reasons for the high rate of HIV and teen pregnancy in this population such as extreme poverty, poor health care, lack of language skills, it is probable that the lack of education and skills to practice safer sex is a factor in the high rate of HIV and teen pregnancy in this community. It is important for parents to provide the information that the schools are not making available to the students. In the area of sex education this could be the difference between life and death.

Future studies regarding this topic should focus on men's views of sex, sexuality, communication between parent and child, and condom use. Also, the children's views regarding sex education, both formal and informal should be studied so definitive information regarding where children are receiving sexuality education can be ascertained.

\section{References}

Cartwright, E., \& Solis, A. (2002). HIV/AIDS: Perceptions among the hispanic communities of southeast Idaho. Unpublished report for Idaho Department of Health and Welfare. Department of Anthropology. Idaho State University, Pocatello, ID.

Centers for Disease Control and Prevention. (2004). HIV/AIDS Surveillance Report, Volume 16. Table 3. Estimated numbers of AIDS cases, by year of diagnosis and selected characteristics of persons, 2000-2004 - United States. Retrieved May 29, 2006, from http://www.cdc.gov/hiv/topics/surveillance/resources/reports/2004report/table3.htm

Hamilton, B. E., Ventura, S. J., Martin, J. A., \& Sutton, P. D. (2005). Preliminary births for 2004. Health E-Stats. Retrieved February 16, 2006, from http://www.cdc.gov/nchs/products/pubs/

Idaho Department of Health and Welfare. (2006). Idaho HIV/AIDS and STD statistics - 1st Quarter 2006. Retrieved May 8, 2006, from http://www.healthandwelfare.idaho.gov/Portals/ Rainbow/Documents/health/df5646fe-1c0d4403-8a51-76299023591e.pdf

Marin, B. V., Tschann, J. M., Gomez, C. A., \& Kegeles, S. M. (1993). Acculturation and gender differences in sexual attitudes and behaviors: hispanic vs. non-hispanic white unmarried adults. American Journal of Public Health, 83, 1759-1761.

Marks, G., Cantero, P. J., \& Simoni, J. M. (1998). Is acculturation associated with sexual risk behaviours? An investigation of HIV-positive Latino men and women. AIDS Care 10(3), 283-295.

Newcomb, M. D., Wyatt, G. E., Romero, G. J., Tucker, M. B., Wayment, H. A., Vargas-Carmona, J. H., Solis, B., \& Mitchell-Kernan, C. (1998). Acculturation, sexual risk taking, and HIV health promotion among Latinas. Journal of Counseling and Psychology, 45, 454-467.

Peragalla, N. (1996). Latino women and AIDS risk. Public Health Nursing, 13, 217-222. 
Rangel, G., \& Lozada, R. (2003). Factores de riesgo de infección por VIH en emigrantes mexicanos: el caso de los emigrantes que llegan a la Casa del Migrante CentroEscalabrini y Ejército de Salvación. El Colegio de la Frontera Norte, ISESALUD/COMUSIDA.

Rice, P., \& Ezzy, D. (1999). Qualitative research methods: A health focus. Melbourne: Oxford University Press.

Stahlman, J. (2004). HIV and AIDS knowledge in a rural Mexican village. Unpublished masters thesis. Department of Anthropology, Idaho State University, Pocatello, ID.

\title{
Acknowledgements
}

This research is a product of the Hispanic Health Projects at the Department of Anthropology at Idaho State University.

\author{
Author Information \\ Peter C. Davis, Jr., MHE, MA \\ Research Associate \\ Institute for Rural Health \\ Idaho State University - Boise Center \\ 12301 W. Explorer \#102 \\ Boise, ID 83713 \\ E-Mail: davipete@isu.edu \\ Linda L. Rankin, PhD, RD, FADA \\ Associate Professor \\ Department of Health and Nutrition Sciences \\ Idaho State University \\ Campus Box 8109 \\ Pocatello, ID 83209 \\ E-Mail: ranklind@isu.edu
}

